\title{
EARTHWORMS (Annelida: Oligochaeta) OF THE CON DAO ARCHIPELAGO
}

\author{
Nguyen Thanh Tung,"*, Nguyen Thi Bao Ngoc ${ }^{2}$, Nguyen Duc Anh ${ }^{3}$ \\ ${ }^{1}$ Department of Biology, School of Education, Can Tho University, Can Tho City, Vietnam \\ ${ }^{2}$ Center for Continuing Education, Thai Lai District, Can Tho city, Vietnam \\ ${ }^{3}$ Department of Soil Ecology, Institute of Ecology and Biological Resources, VAST, Vietnam
}

Received 6 October 2020, accepted 16 March 2021

\begin{abstract}
The earthworms of the Con Dao archipelago are investigated based on literature and newly collected specimens. A total of 16 species belonging to seven genera in three families are documented in Con Son and Bay Canh islands. The species, Polypheretima grandisetosa (Thai, 1996) is re-described from holotype and freshly collected specimens. All species are imaged for recognition. An identification key to all earthworm species is provided for the Con Dao archipelago.
\end{abstract}

Keywords: Megascolecidae, taxonomy, biodiversity, identification key, Vietnam.

Citation: Nguyen T. T, Nguyen T. B. N, Nguyen D. A, 2021. Earthworms (Annelida: Oligochaeta) of the Con Dao Archipelago. Academia Journal of Biology, 43(1): 9-27. https://doi.org/10.15625/2615-9023/15559

*Corresponding author email: thanhtung@ctu.edu.vn

(C2021 Vietnam Academy of Science and Technology (VAST) 


\section{INTRODUCTION}

The Con Dao archipelago in Ba Ria Vung Tau Province, southern Vietnam, has 16 islands located between $8^{\circ} 37^{\prime}-8^{\circ} 48^{\prime} \mathrm{N}$, and $106^{\circ} 31^{\prime}-106^{\circ} 45^{\prime}$ E. Of which, Con Son island is the largest one with an area of 5.740 ha, followed by Bay Canh island (702 ha). The archipelago is in a humid subtropical climate zone, with a temperature range from $25.8{ }^{\circ} \mathrm{C}$ to $29.8{ }^{\circ} \mathrm{C}$. The rainy season starts in May and lasts until November, with an average annual rainfall of 2,575 mm (Tran et al. 2012). The Con Dao archipelago is mostly covered with evergreen and semi-evergreen forests on lowrelief mountains (Sterling et al. 2008).

The first record of earthworms in the Con Dao archipelago was samples of Amynthas heterochaetus (= A. corticis) collected by Maindron in 1907 (Jamieson 1975). Thai (1996) described two new acaecate earthworms from specimens collected in Con Son and Bay Canh islands, namely Pheretima colonensis Thai, 1996 (=Polypheretima colonensis) and Pheretima grandisetosa Thai, 1996 (=Polypheretima grandisetosa). Thai et al. (2004) reported the occurrence of other seven species in Con Son and Bay Canh islands, including Pontoscolex corethrurus
(Müller, 1856), Pontodrilus litoralis (Grube, 1855), Polypheretima grandisetosa (Thai, 1996), Po. colonensis (Thai, 1996), Metaphire anomala (Michaelsen, 1907), M. bahli (Gates, 1945), M. posthuma (Vaillant, 1868), Amynthas corticis (Kinberg, 1867), Dichogaster bolaui (Michaelsen, 1891).

Continuing our research on the earthworms of Vietnam, this paper aims to provide the better knowledge on the earthworms of the Con Dao archipelago based on the previously and freshly collected specimens. The re-description is also provided to poorly known species.

\section{MATERIALS AND METHODS}

Earthworms were manually searched for and collected from 36 sampling sites in natural forests and residential gardens in October 2019 (Fig. 1). After collection, specimens were cleaned by tap water, killed in formalin $2 \%$, temporally fixed in formalin $4 \%$ for 12 hours, then transferred to new formalin $4 \%$ for long-term preservation. All specimens including holotypes and paratypes were deposited in Laboratory of Zoology, Department of Biology, Can Tho University.

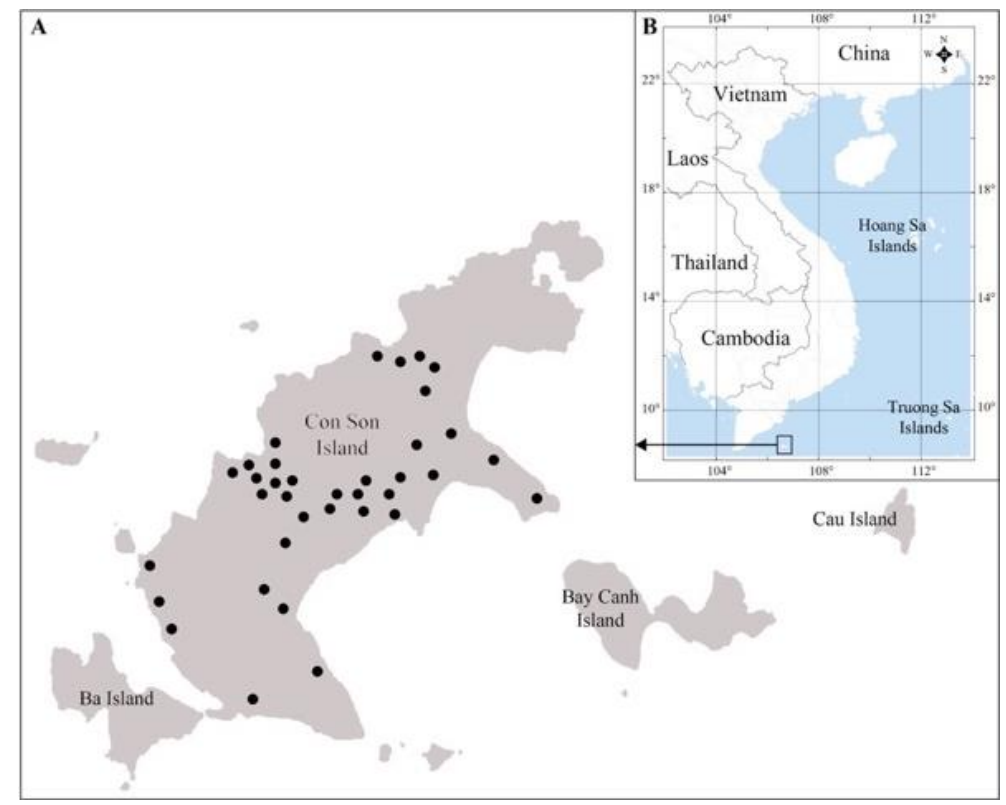

Figure 1. Collecting sites in the Con Dao archipelago 
Materials were examined under a Motic Digital microscope (Model: DM143-FBGGC), and dissected from the dorsal side for internal observation. Transverse body sections were processed using the classical method of haematoxylin and eosin. Selected segments were cleaned and dehydrated using graded ethanol concentrations. Segments were treated with paraffin, then cut using a microtome Sakura Accu SRM 200CW. Cut sections were stained using haematoxylin and eosin $\mathrm{Y}$ (Feldman and Wolfe 2014), then transferred onto glass slides.

Colour images were taken using a camera attached directly to the microscope. Line drawings and colour images were improved and grouped into plates using Photoshop CS6.

Abbreviations. CTU $=$ Can Tho University, $\mathrm{ag}=$ accessory gland, $\mathrm{amp}=$ ampulla, $\mathrm{cl}=$ clitellum, $\mathrm{cgl}=$ calciferus gland, $\mathrm{dv}=$ diverticulum, $\mathrm{gm}=$ genital marking, $\mathrm{gz}=$ gizzard, $\mathrm{mp}=$ male pore, prp $=$ prostatic pore, $\mathrm{sg}=$ seminal groove, $\mathrm{ps}=$ penial seta, $\mathrm{ov}=$ ovary, $\mathrm{sp}=$ spermathecal pore, $\mathrm{ts}=$ testis sac, $\mathrm{sv}=$ seminal vesicle, $\mathrm{st}=$ seta.

\section{RESULTS}

\section{Taxonomic account}

\section{0}

Family RHINODRILIDAE Benham,

\section{Genus Pontoscolex Schmarda, 1861}

Pontoscolex corethrurus (Müller, 1856)

Materials examined. 29 matures (CTUEW.001.39), residential garden, $8^{\circ} 43^{\prime} 44 \mathrm{~N}$ 106 $37^{\circ} 39 \mathrm{E}, 10 \mathrm{~m}, 18$ Oct. 2019; 19 matures (CTU-EW.001.40), natural forest, $8^{\circ} 40^{\prime} 5 \mathrm{~N}$ $106^{\circ} 35^{\prime} 48 \mathrm{E}, 10 \mathrm{~m}$, Con Son Island, Ba RiaVung Tau Province, 19 Oct. 2019, leg. Nguyen Thanh Tung and Nguyen Thi Bao Ngoc.
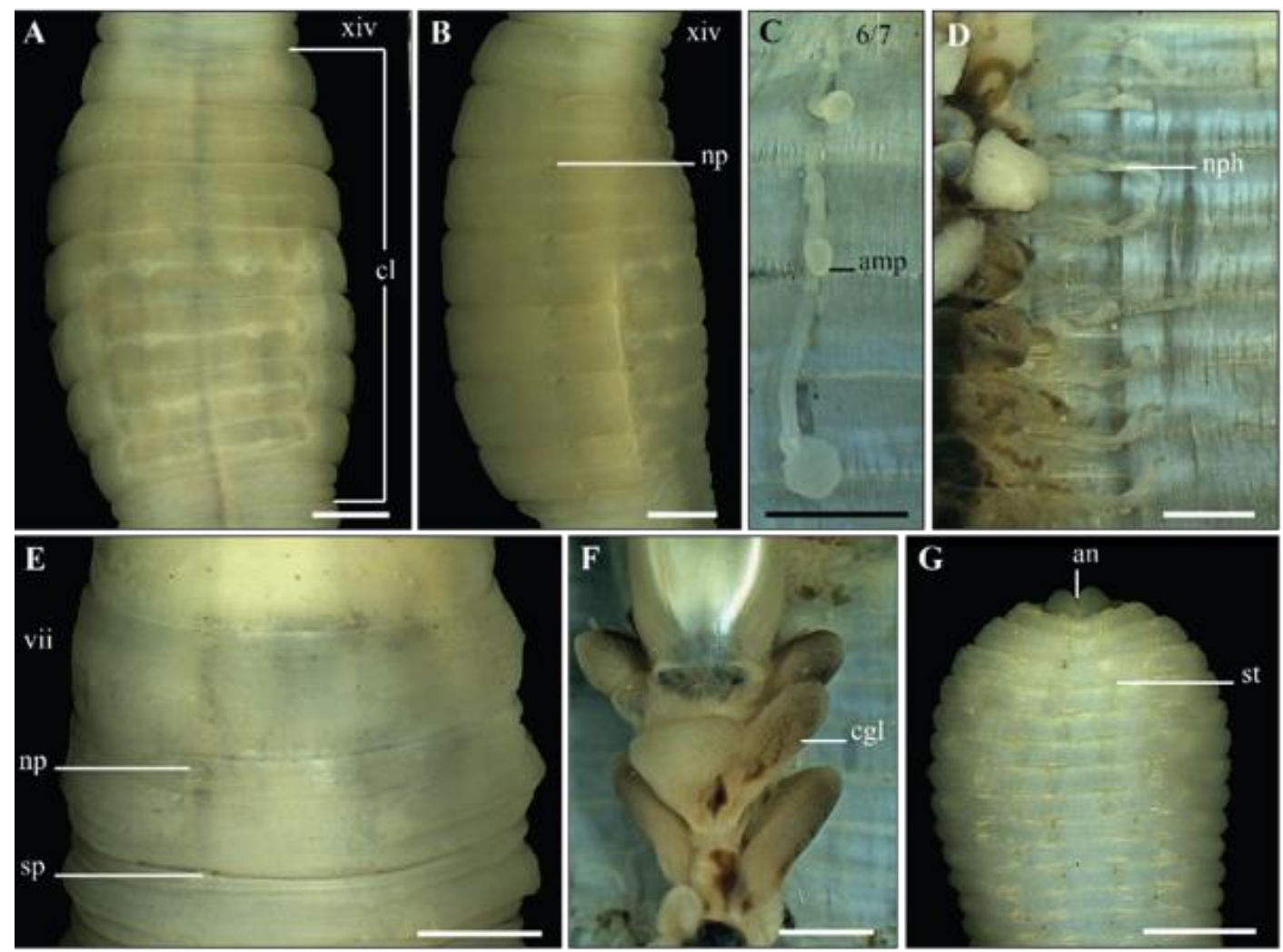

Figure 2. Pontoscolex corethrurus (Müller, 1856), A. Ventral view of clitellum; B: Lateral view of clitellum; C: Left spermathecae; D: Nephridia; E: Lateral view of spermathecal region; F: Calciferus glands; G: Ventral view of tail; Scale bar $=1 \mathrm{~mm}$ 
Diagnosis. Lumbricine. Medium-sized worm. Tail setae long and alternative formed longitudinal spiral-shaped. Three pairs of spermathecal pores in lateral intersegments 6/7/8/9. Clitellum saddle-shaped, within xvxxi or $x v-x x i i$. Calciferous glands opened through sacs, three pairs in vii, viii and ix. Nephridia holoic, one pair per segment. Spermathecae without diverticula.

Habitat and ecology. The species was commonly found at elevations less than $40 \mathrm{~m}$ asl.

Remarks. The species is known to be originally from South America (Brown et al. 2006). However, the species is now widely distributed in tropical region.

Family MEGASCOLECIDAE Rosa, 1891

Genus Lampito Kinberg, 1866

\section{Lampito mauritii (Kinberg, 1866)}

Materials examined. 18 matures (CTU.EW.002.22), residential gardens, $8^{\circ} 43^{\prime} 46 \mathrm{~N} 106^{\circ} 37^{\prime} 40 \mathrm{E}, 10 \mathrm{~m}$, Con Son Island, Ba Ria-Vung Tau Province, 18 October 2019, leg. Nguyen Thanh Tung and Nguyen Thi Bao Ngoc.

Diagnosis. Medium-sized worm. Prostomium epilobous. Clitellum annular, within xiv-xvi. Spermathecal pores 3 pairs in ventrolateral intersegments 6/7/8/9. Genital markings absent. Male pores on large pads extending to the entire length of segment xviii. Penial setae present. Spermathecae paired in vii, viii and ix; each spermatheca with two diverticula. Holandric. Intestine without caeca. Septa 4/5/6 absent. Oesophageal gizzard in v-vi.
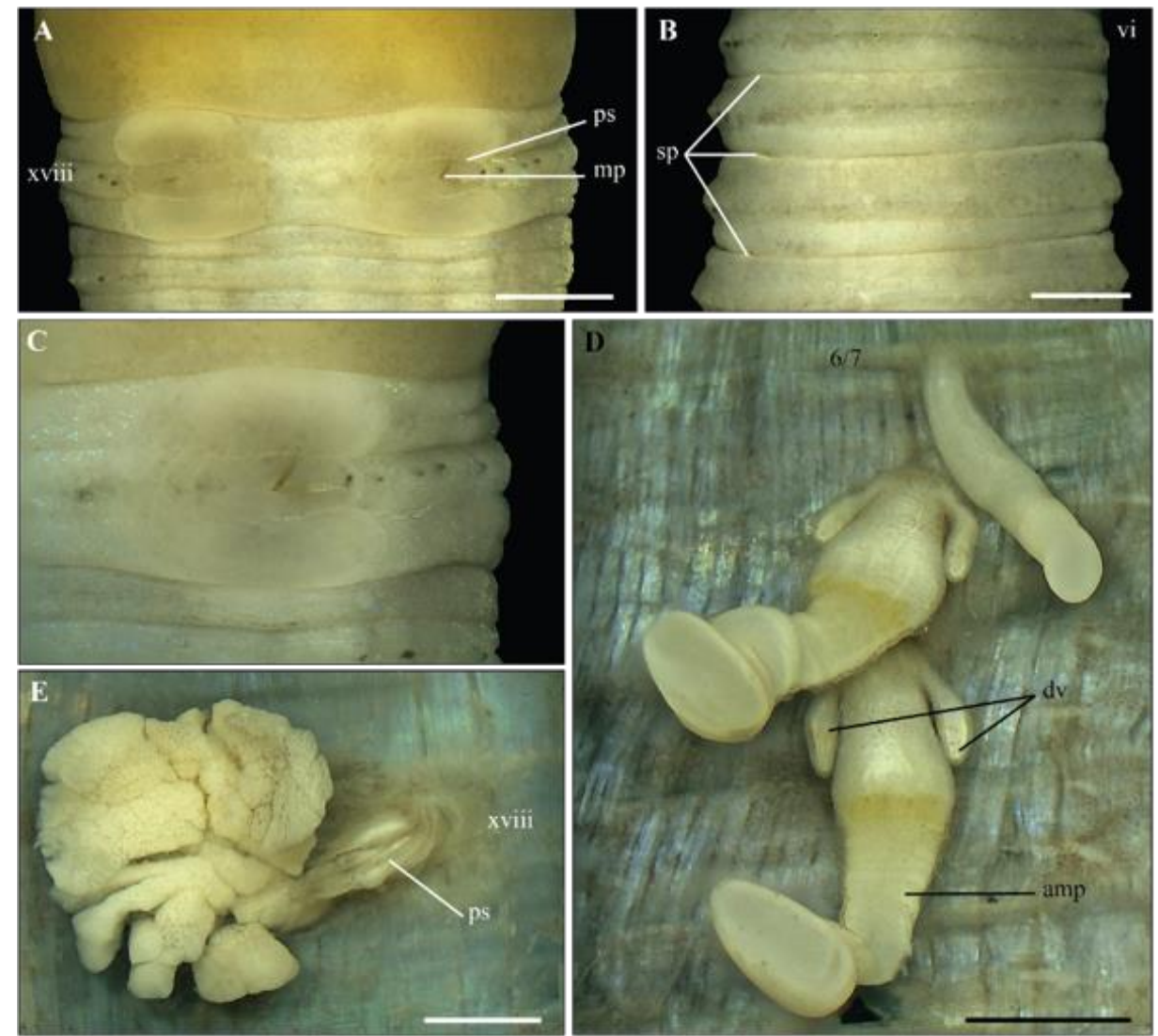

Figure 3. Lampito mauritii (Kinberg, 1866), A. Ventral view of male pores region; B: Ventral view of spermathecal pores region; C: Right male porophores; D: Left spermathecae; E: Left prostatic gland; Scale bar $=1 \mathrm{~mm}$ 
Remarks. Two specimens lack diverticula in the spermathecae of segment vii.

\section{Genus Perionyx Perrier, 1872}

Perionyx excavatus Perrier, 1872
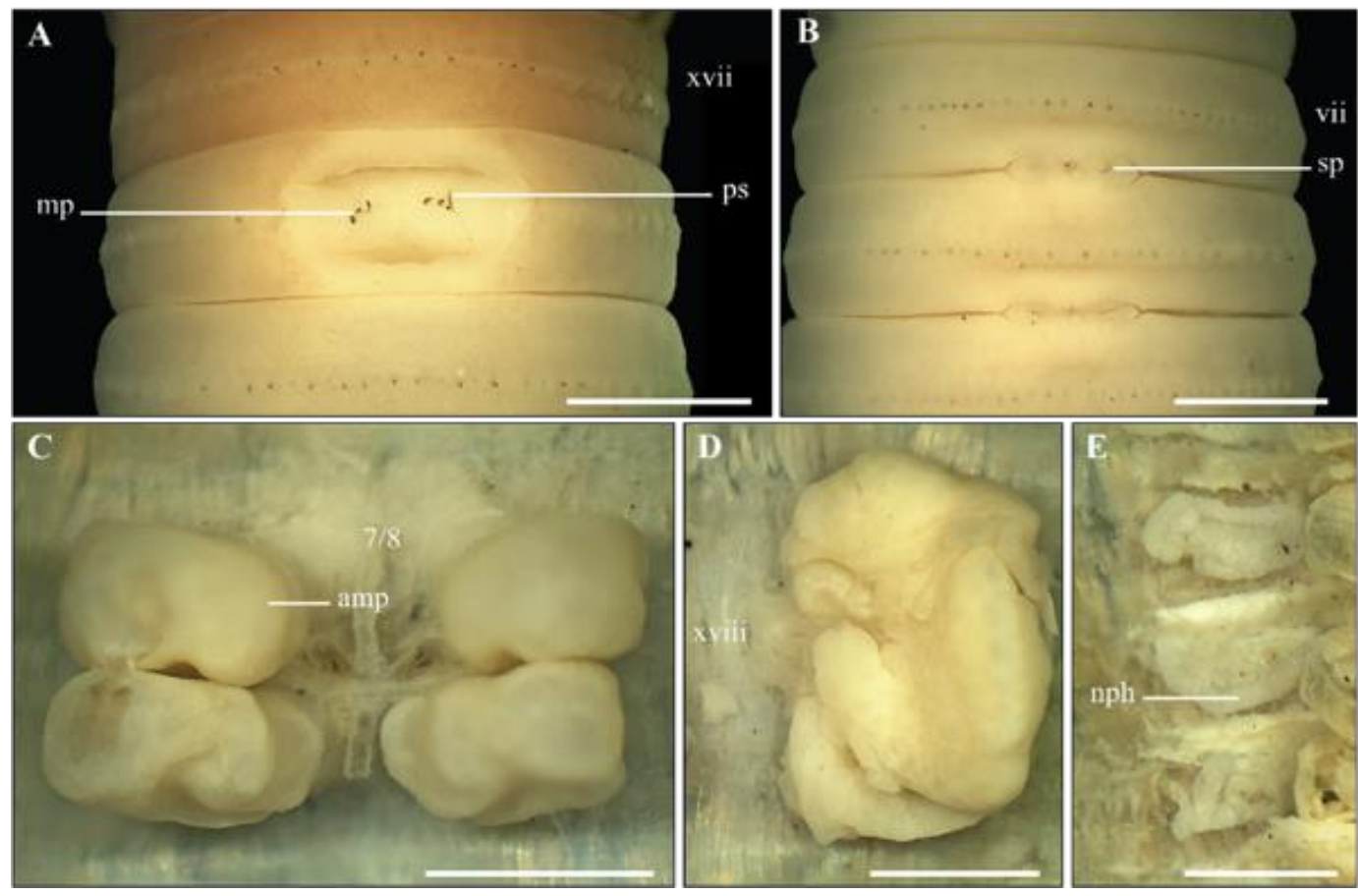

Figure 4. Perionyx excavatus (Perrier, 1872), A. Ventral view of male pores region; B: Ventral view of spermathecal pores region; C: Spermathecae; D: Right prostatic gland; E: Nephridia;

Scale bar $=1 \mathrm{~mm}$

Materials examined. 1 mature (CTUEW.003.04), residential garden, $8^{\circ} 43^{\prime} 46 \mathrm{~N}$ $106^{\circ} 37^{\prime} 40 \mathrm{E}, 10 \mathrm{~m}$, Con Son Island, Ba RiaVung Tau Province, 18 October 2019, leg. Nguyen Thanh Tung and Nguyen Thi Bao Ngoc.

Diagnosis. Medium-sized worm. Clitellum annular, within xiii-xvii. Prostomium epilobous. First dorsal pore in 4/5. Two pairs of spermathecal pores in mid-ventral intersegments 7/8/9. Male pores located inside oval, concave region in the medioventral xviii. Penial setae present. Spermathecae paired in viii and ix. Spermathecae without diverticula. Nephridia holoic. Intestinal caeca and oesophageal gizzard absent.

Remarks. Only one specimen was found in the top soil containing cow manures in short-term tree garden, near residential areas.

\section{Genus Amynthas Kinberg, 1867}

\section{Amynthas corticis (Kinberg, 1867)}

Materials examined. 18 matures (CTUEW.052.03), Con Son Island, Ba Ria-Vung Tau Province, 26 June 1989, leg. Thai Tran Bai.

Diagnosis. Medium-sized worm. Prostomium epilobous. Clitellum annular, within xiv-xvi. First dorsal pore in 12/13. Four pairs of spermathecal pores in ventrolateral intersegments 5/6/7/8/9. Male pores on the setal ring in xviii; copulatory pouches absent. Genital markings paired in xviii, but single (if present) in medioventral v-viii. Spermathecae paired in vi-ix. Holandric. Testis sacs separated. Intestinal caeca simple. Septa 8/9/10 absent.

Remarks. Jamieson (1975) and Thai et al. (2004) reported the presence of Amynthas 
corticis in residential gardens in Con Son and specimens were found in our investigation in Bay Canh Islands. Unfortunately, no October 2019.

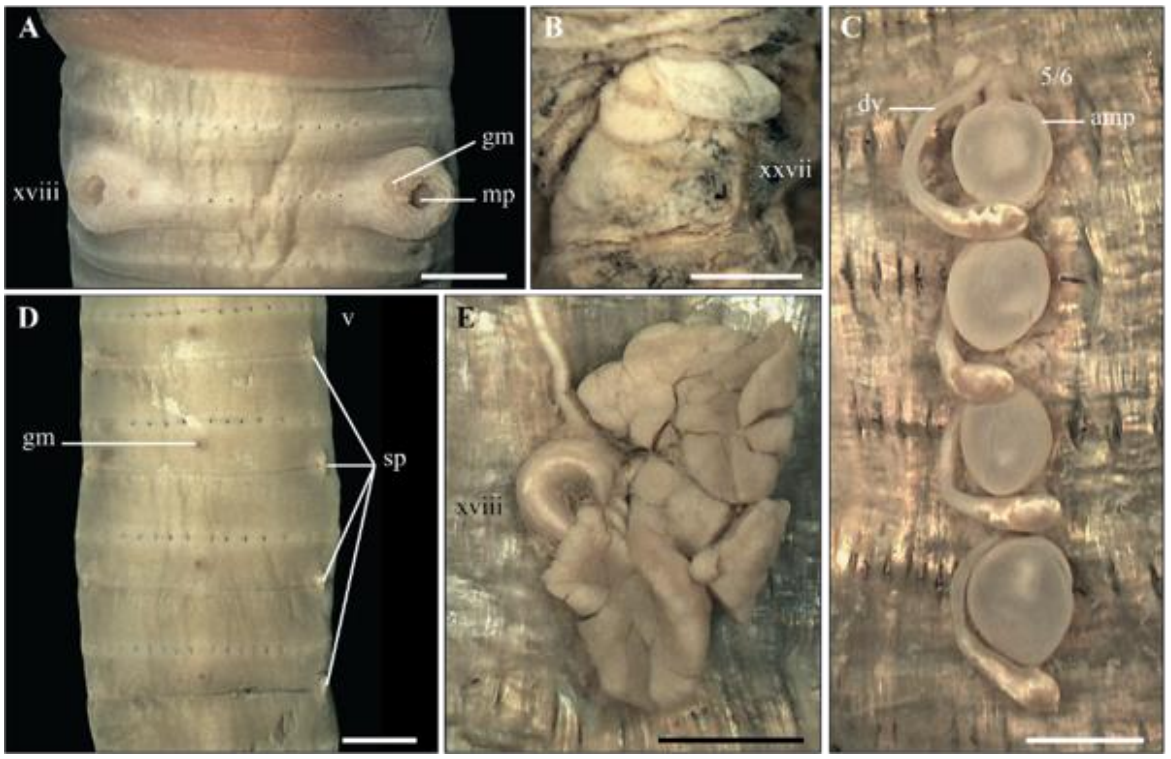

Figure 5. Amynthas corticis (Kinberg, 1867), A. Ventral view of male pores region; B: Intestinal caecum; C: Left spermathecae; D: Ventral view of spermathecal pores region; E: Right prostatic gland; Scale bar $=1 \mathrm{~mm}$

\section{Genus Metaphire Sims \& Easton, $1972 \quad$ Metaphire bahli (Gates, 1945)}
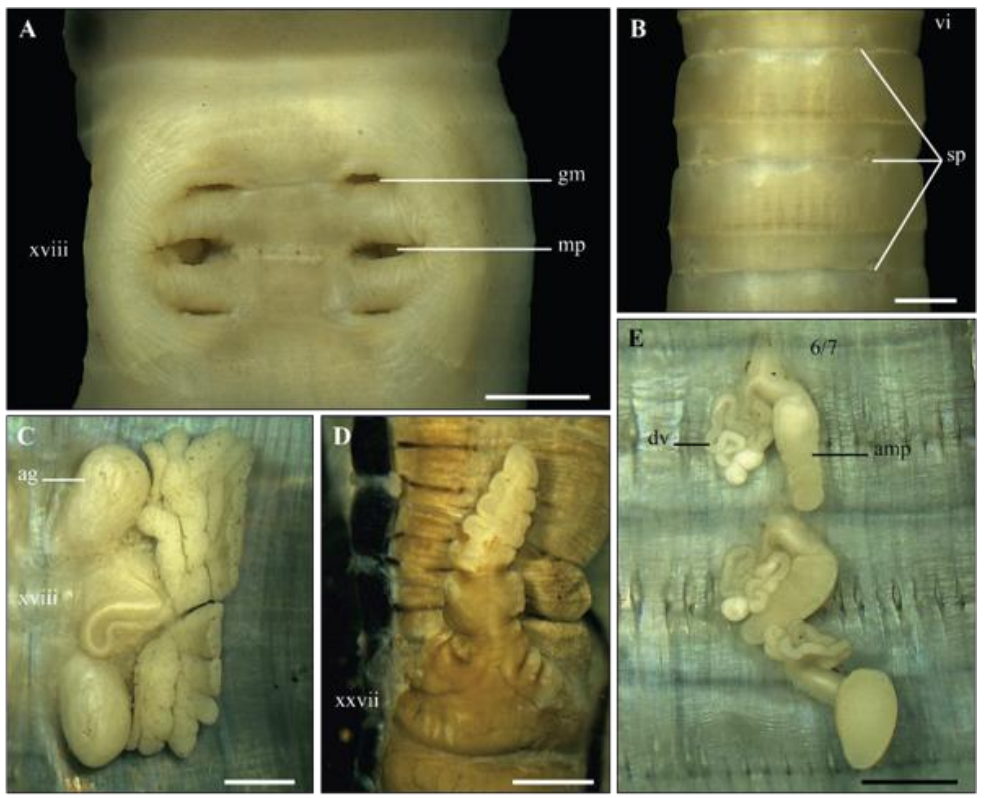

Figure 6. Metaphire bahli (Gates, 1945), A. Ventral view of male pores region; B: Ventral view of spermathecal pores region; C: Right prostatic gland; D: Intestinal caecum; E: Right spermathecae; Scale bar $=1 \mathrm{~mm}$ 
Materials examined. 67 matures (CTUEW.004.49), natural forest, $8^{\circ} 43^{\prime} 50 \mathrm{~N}$ $106^{\circ} 37^{\prime} 31 \mathrm{E}, 10 \mathrm{~m}$, Con Son Island, Ba RiaVung Tau Province, 18 October 2019; 18 matures (CTU-EW.004.50), residential garden, $8^{\circ} 41^{\prime} 32 \mathrm{~N} ; 106^{\circ} 37^{\prime} 19 \mathrm{E}, 10 \mathrm{~m}, 20$ October 2019, leg. Nguyen Thanh Tung and Nguyen Thi Bao Ngoc.

Diagnosis. Medium-sized worm. Prostomium epilobous. Clitellum annular, within xiv-xvi. First dorsal pore in 12/13. Three pairs of spermathecal pores in ventrolateral intersegments 6/7/8/9. Male pores on the setal ring in xviii; copulatory pouches present. Two pairs of genital markings in $17 / 18$ and $18 / 19$. Both male pores and genital markings located in a concave area of the male region. Holandric. Testis sacs in $\mathrm{x}-\mathrm{xi}$, separated. Intestinal caeca simple. Septa 8/9/10 absent, 10/11 present ventrally.

Habitat and ecology. The species was commonly found in Con Son Island, more densely populated in residential gardens and forest edges, but absent in deep forests.
Remarks. In comparison with other populations, Metaphire bahli specimens found in the Con Son island have septum 10/11 presented ventrally.

\section{3)}

Metaphire easupana (Thai \& Huynh,

Materials examined. 11 matures (CTUEW.012.23), forest edge, $8^{\circ} 39^{\prime} 53 \mathrm{~N}$ $106^{\circ} 34^{\prime} 00 \mathrm{E}, 40 \mathrm{~m}$, Con Son Island, Ba RiaVung Tau Province, 19 October 2019; 20 matures (CTU-EW.012.24), natural forest, $8^{\circ} 42^{\prime} 17 \mathrm{~N} 106^{\circ} 35^{\prime} 28 \mathrm{E}, 50 \mathrm{~m}, 19$ October 2019, leg. Nguyen Thanh Tung and Nguyen Thi Bao Ngoc.

Diagnosis. Medium-sized worm. Prostomium epilobous. Clitellum annular, within xiv-xvi. First dorsal pore in 12/13. One pair of spermathecal pores in ventrolateral intersegment 5/6. Male pores on the setal ring in xviii; copulatory pouches present. Genital markings absent. Holandric. Testis sacs connected ventrally. Intestinal caeca manicate. Septa 8/9/10 absent.

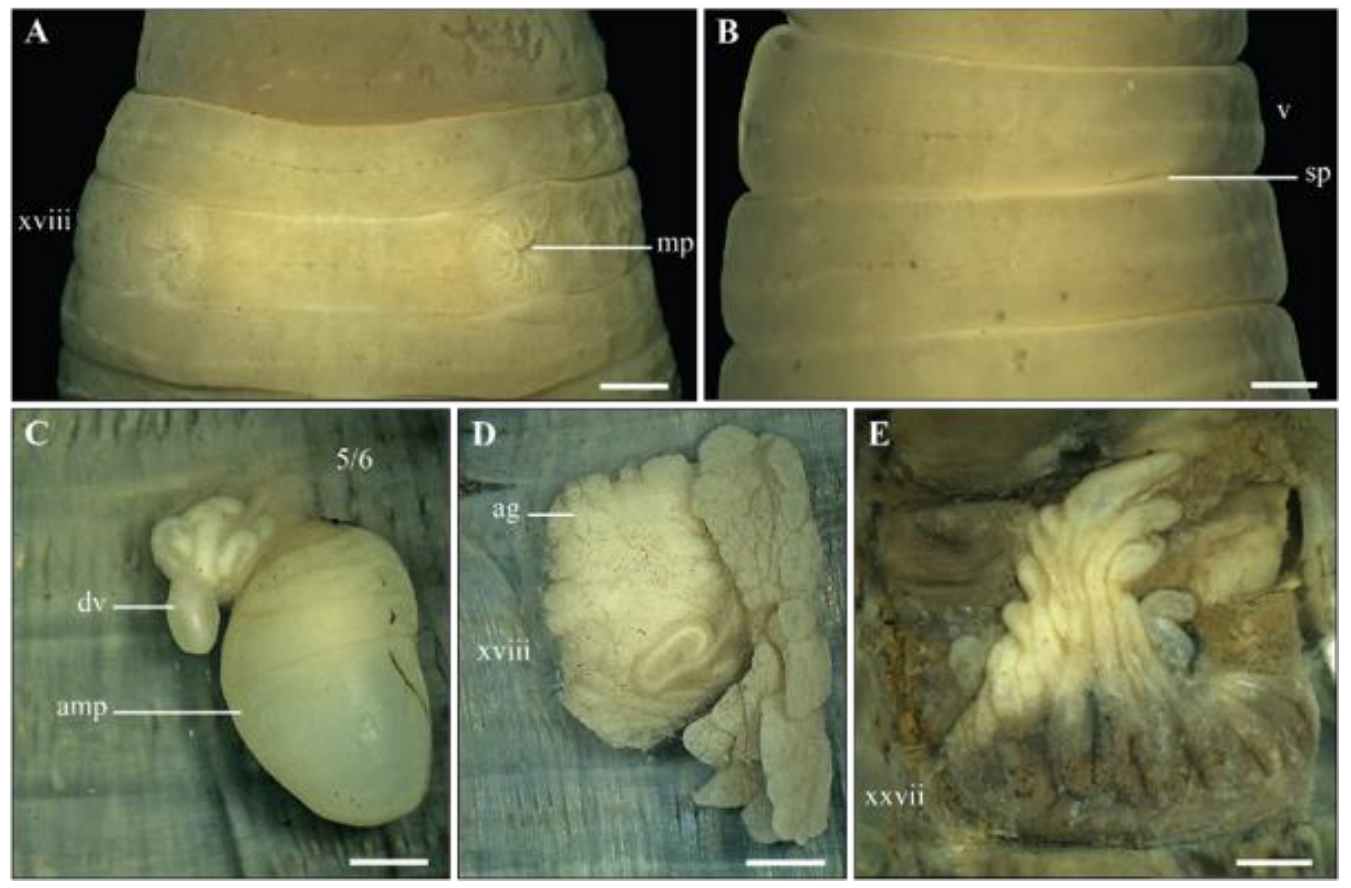

Figure 7. Metaphire easupana (Thai \& Huynh, 1993), A: Ventral view of male pores region; B: Ventral view of spermathecal pores region C: Right spermatheca; D: Right prostatic gland; E: Intestinal caecum; Scale bar $=1 \mathrm{~mm}$ 
Remarks. The species was found only in leaf litter or in topsoil of natural forests. Their dark-brown body has a violet hue when alive. Movements similar to caterpillar locomotion. Specimens collected in Con Son island have minor differences compared to the original description and other populations found in the mainland (An Giang, Ba Ria-Vung Tau, Dong Nai). Our specimens have one pair of spermathecal pores in $5 / 6$, diverticula shorter than ampulla length, copulatory pouches covered by accessory glands, intestinal origin at $\mathrm{xv}$, and larger size $(1=112-136 \mathrm{~mm}, \mathrm{~d}=$ $6.2-7.8 \mathrm{~mm}$ ). On the contrary, the original description and other population have two pairs of spermathecal pores in $5 / 6 / 7$, diverticula being longer than ampulla, accessory glands absent, intestinal origin at xiv and smaller size $(\mathrm{l}=68-138 \mathrm{~mm}, \mathrm{~d}=3.9-6 \mathrm{~mm}$ ) (Thai et al. 1993; Nguyen et al. 2017b, 2019).

\section{Metaphire houlleti (Perrier, 1872)}
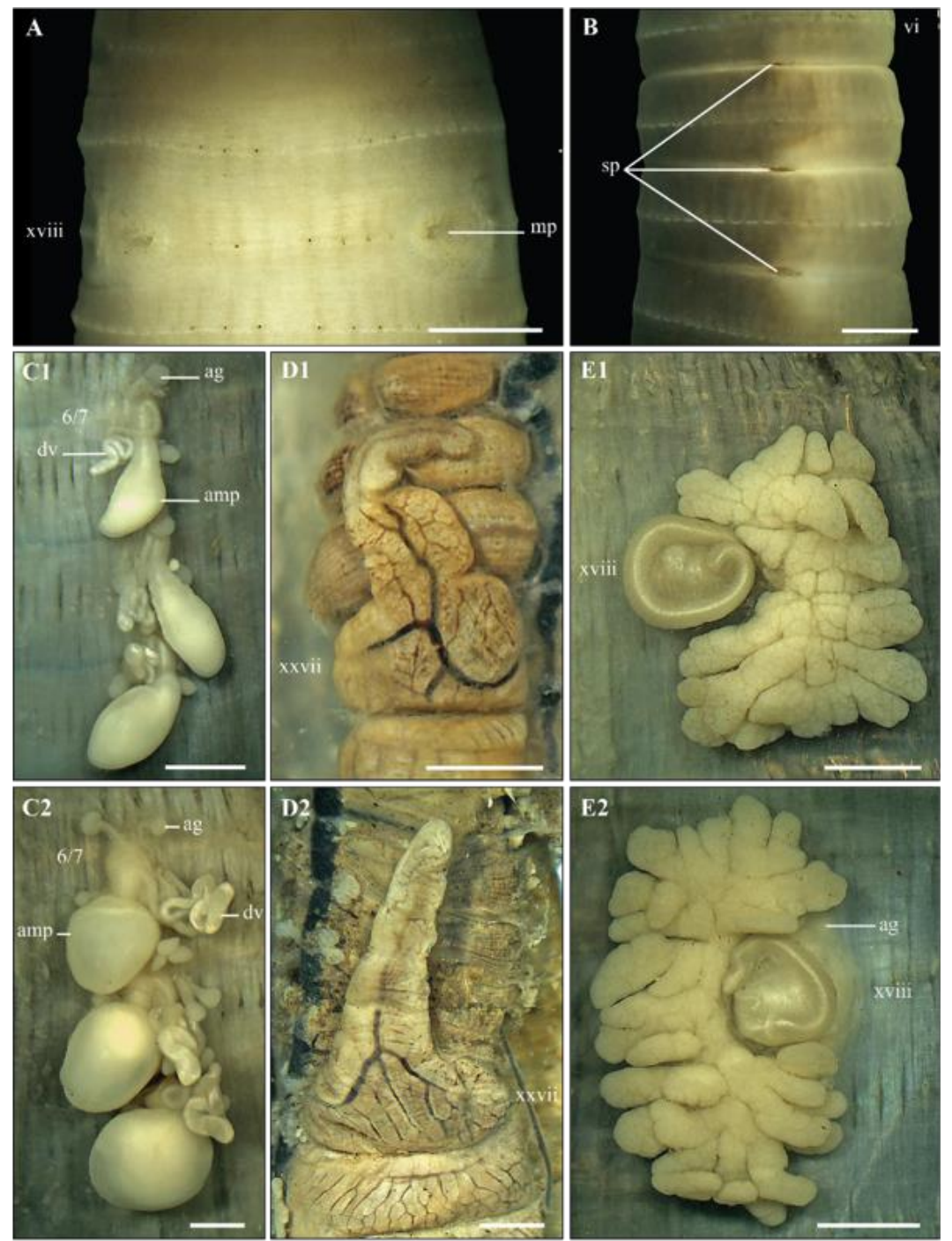

Figure 8. Metaphire houlleti (Perrier, 1872), A. Ventral view of male pores region; B: Lateral view of spermathecal pores region; C1, C2: Spermathecae; D1, D2: Intestinal caecum; E1, E2: Prostatic gland; Scale bar $=1 \mathrm{~mm}$ (1-community in residential areas, 2 -community in natural forest) 
Materials examined. 7 matures (CTUEW.006.39), residential garden, $8^{\circ} 41^{\prime} 18 \mathrm{~N}$ $106^{\circ} 35^{\prime} 45 \mathrm{E}, 40 \mathrm{~m}$, Con Son Island, Ba RiaVung Tau Province, 19 October 2019; 25 matures (CTU-EW.006.41), natural forest, $8^{\circ} 43^{\prime} 50 \mathrm{~N} 106^{\circ} 37^{\prime} 31 \mathrm{E}, 10 \mathrm{~m}$, Con Son Island, Ba Ria-Vung Tau Province, 18 October 2019; 38 matures (CTU-EW.006.42), natural forest, $8^{\circ} 41^{\prime} 56 \mathrm{~N} 106^{\circ} 35^{\prime} 47 \mathrm{E}, 40 \mathrm{~m}$, Con Son Island, Ba Ria-Vung Tau Province, 19 October 2019, leg. Nguyen Thanh Tung and Nguyen Thi Bao Ngoc.

Diagnosis. Medium-sized worm. Prostomium epilobous. First dorsal pore variable, in $9 / 10$ or $10 / 11$ or $11 / 12$. Clitellum annular, within xiv-xvi. Three pairs of spermathecal pores in ventrolateral intersegments 6/7/8/9. Male pores on the setal ring in xviii; copulatory pouches present. Genital markings absent. Holandric. Testis sacs connected. Penial setae absent. Intestinal caeca simple. Septa 8/9/10 absent.

Remarks. Two different types were collected in the Con Son island. The first type was found in residential gardens, and has smaller size (length $=40-105$, diameter $=$ 2.8-3.8, segment = 55-108), ovoid spermathecal ampulla with equal ducts. The second type was found in natural forests, and have larger size (length $=123-160$, diameter $=3.8-5.0$, segment $=96-125)$, mushroomshaped spermathecal ampulla with short ducts.

\section{Metaphire peguana peguana (Rosa, 1890)}
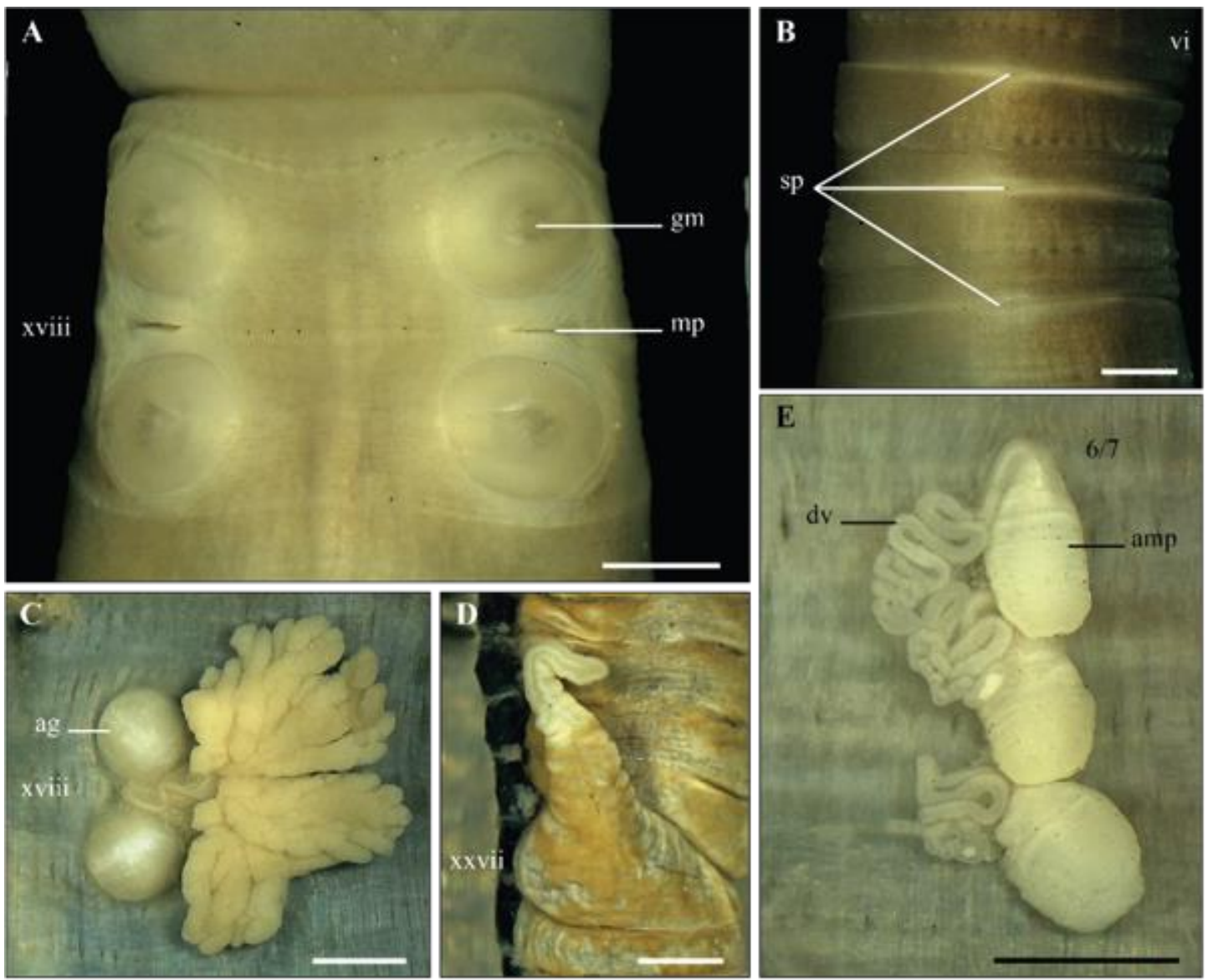

Figure 9. Metaphire peguana peguana (Rosa, 1890), A. Ventral view of male pores region; B: Lateral view of spermathecal pores region; C: Right prostatic gland; D: Intestinal caecum; E: Right spermathecae; Scale bar $=1 \mathrm{~mm}$ 
Materials examined. 3 matures (CTUEW.009.20), residential garden, $8^{\circ} 41^{\prime} 59 \mathrm{~N}$ 106 36'54E, $10 \mathrm{~m}, 20$ October 2019, leg. Nguyen Thanh Tung and Nguyen Thi Bao Ngoc.

Diagnosis. Medium-sized worm. Prostomium epilobous. Clitellum annular, within xiv-xvi. First dorsal pore in 12/13. Three pairs of spermathecal pores in ventrolateral intersegments 6/7/8/9. Male pores on setal ring in xviii; copulatory pouches present. Two pairs of disc-shaped

genital markings in 17/18 and 18/19. The male region not concave. Holandric. Testis sacs in $\mathrm{x}-\mathrm{xi}$, separated. Accessory glands pouch-like. Intestinal caecae simple. Septa 8/9/10 absent. Septum 10/11 present ventrally.

Remarks. The species was found only in residential gardens. In comparison with other populations, Metaphire peguana peguana found in the Con Son island has septum 10/11 being only present ventrally.

\section{Metaphire planata (Gates, 1932)}
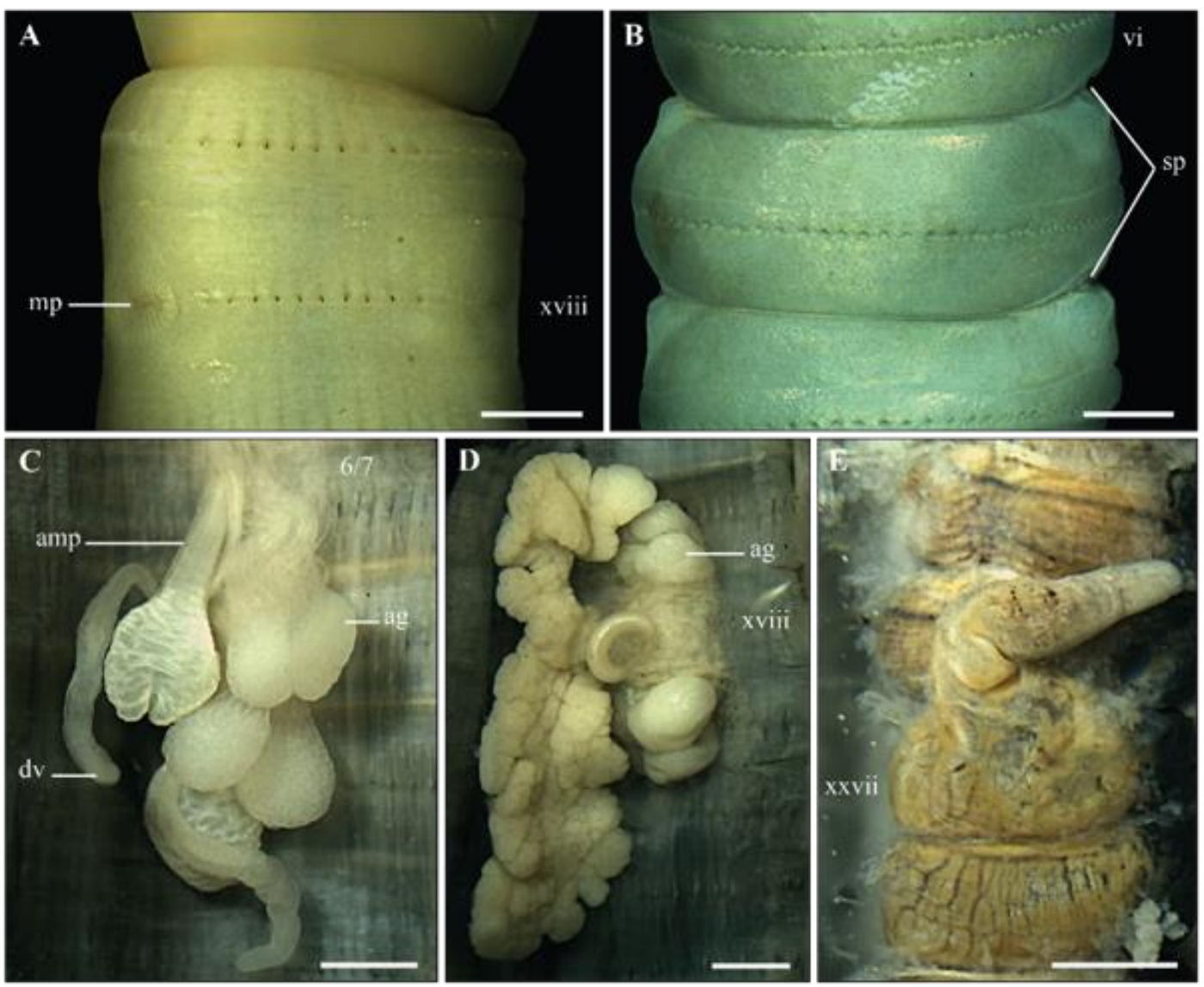

Figure 10. Metaphire planata (Gates, 1932), A. Ventral view of male pores region; B: Lateral view of spermathecal pores region; C: Left spermathecae;

D: Left prostatic gland; E: Intestinal caecum; Scale bar $=1 \mathrm{~mm}$

Materials examined. 9 matures (CTUEW.016.35), residential garden, $8^{\circ} 43^{\prime} 46 \mathrm{~N}$ $106^{\circ} 37^{\prime} 40 \mathrm{E}, 10 \mathrm{~m}, 18$ October 2019 , leg. Nguyen Thanh Tung and Nguyen Thi Bao Ngoc.
Diagnosis. Medium-sized worm. Prostomium epilobous. Clitellum annular, within xiv-xvi. First dorsal pore in 11/12. Two pairs of spermathecal pores in lateral intersegments $6 / 7 / 8$. Male pores on the setal 
ring in xviii; copulatory pouches present. Genital markings variable in number, 1-2 located next to each spermathecal pore. Holandric. Testis sacs separated. Accessory glands numerous, sac-like, attached to the base of spermathecae and copulatory pouches. Intestinal caeca simple. Septa 8/9/10 absent.

Habitat and ecology. The species was found only in residential gardens. It lives at a depth of $0-10 \mathrm{~cm}$ in soft-clay soils mixed with organic matter.

\section{Metaphire posthuma (Vaillant, 1868)}

Materials examined. 1 mature (CTUEW.011.11), residential garden, $8^{\circ} 41^{\prime} 46 \mathrm{~N}$
106 $37^{\prime} 5 \mathrm{E}, 10 \mathrm{~m}, 20$ October 2019, leg. Nguyen Thanh Tung and Nguyen Thi Bao Ngoc.

Diagnosis. Medium-sized worm. Prostomium undeveloped. Clitellum annular, within xiv-xvi. First dorsal pore in 12/13. Four pairs of spermathecal pores in ventrolateral intersegments 5/6/7/8/9. Male pores on the setal ring in xviii; copulatory pouches present. Two pairs of genital markings in xvii and xix. Holandric. Testis sacs connected. Intestinal caeca simple. Septum 8/9 thick, 9/10 absent.

Habitat and ecology. The species was found in soils with organic matters in residential areas.
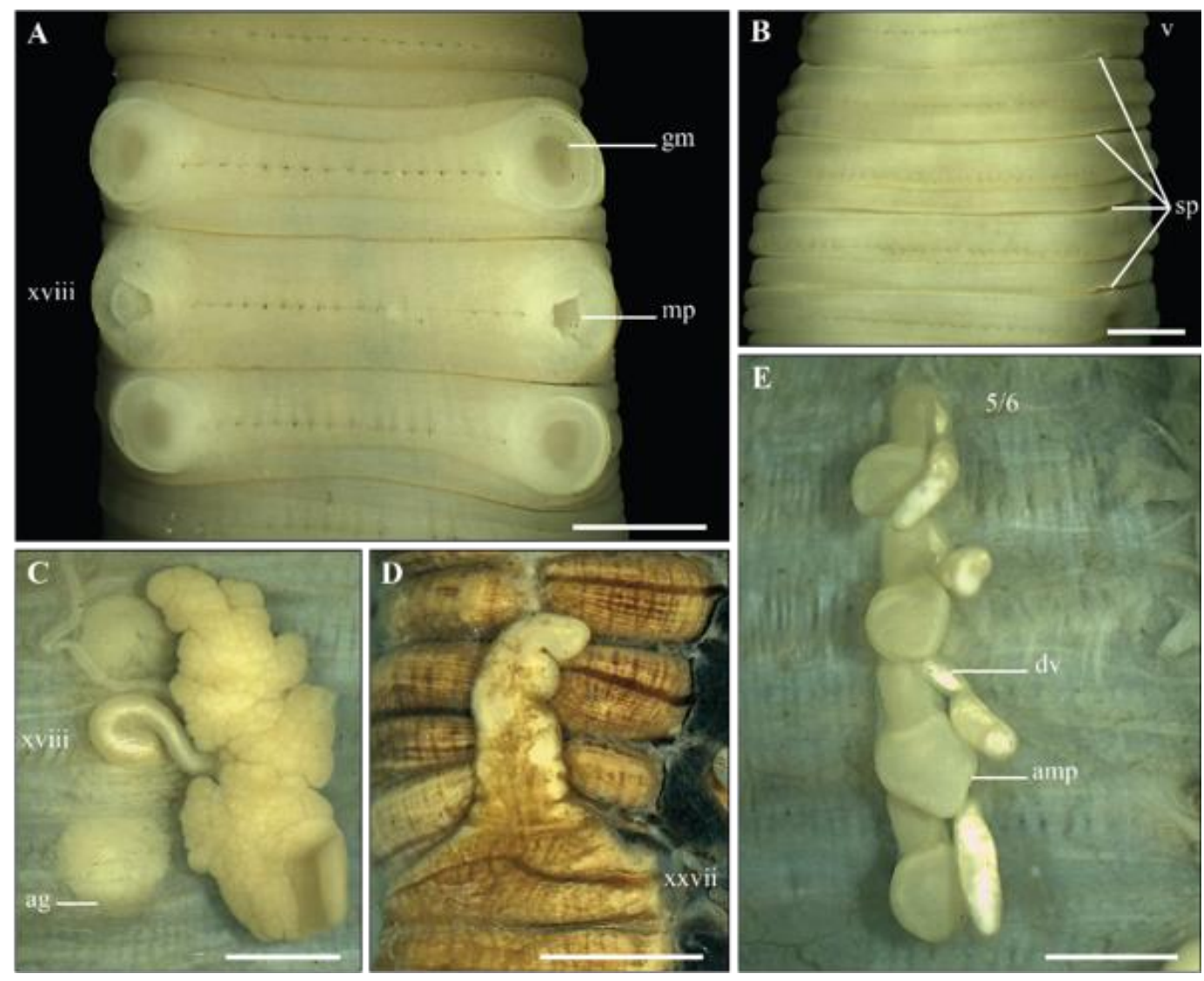

Figure 11. Metaphire posthuma (Vaillant, 1868), A. Ventral view of male pores region; B: Ventral view of spermathecal pores region; C: Right prostatic gland;

D: Intestinal caecum; E: Left spermathecae; Scale bar $=1 \mathrm{~mm}$

Remarks. The species was commonly found in the Mekong Delta (Vietnam) with high density (Nguyen 2014), but only one specimen was collected in the Con Son Island. 


\section{Metaphire sp.1}

Materials examined. 1 mature (CTUEW.020.h01), 9 matures (CTU-EW.020.p02), 16 matures (CTU.EW.020.03), natural forest, $8^{\circ} 42^{\prime} 12 \mathrm{~N} 106^{\circ} 35^{\prime} 41 \mathrm{E}, 120 \mathrm{~m}, 19$ October 2019; 10 mature (CTU.EW.020.04), residential garden, $8^{\circ} 41^{\prime} 59 \mathrm{~N} 106^{\circ} 36^{\prime} 54 \mathrm{E}$,
$10 \mathrm{~m}$, Con Son Island, Ba Ria-Vung Tau Province, 18 October 2019; 33 matures (CTU.EW.020.05), natural forest, $8^{\circ} 39^{\prime} 53 \mathrm{~N}$, $106^{\circ} 34^{\prime} \mathrm{OE}, 20 \mathrm{~m}$, Con Son Island, Ba RiaVung Tau Province, 19 October 2019, leg. Nguyen Thanh Tung and Nguyen Thi Bao Ngoc.
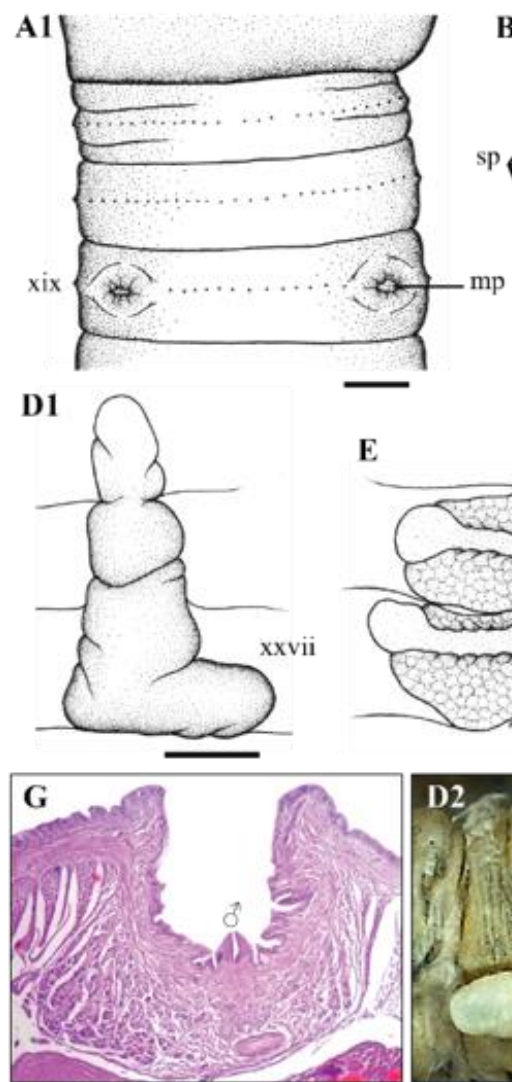

A

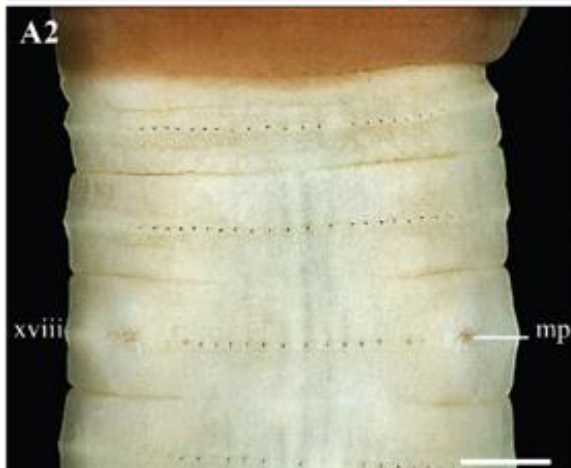

B

E
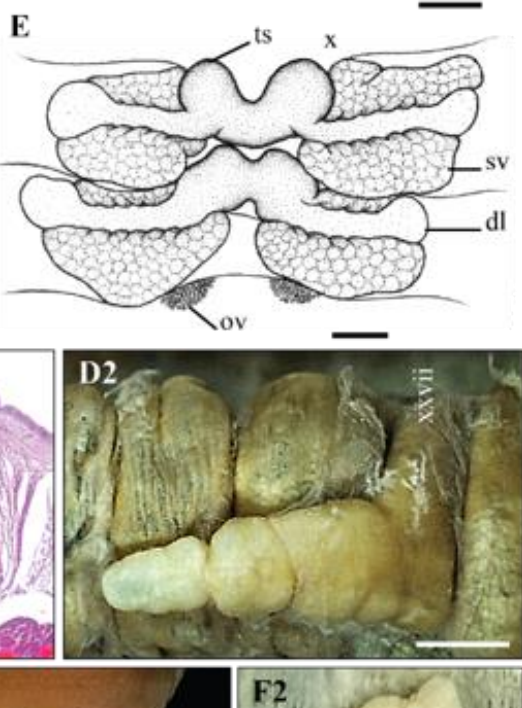

Figure 12. Metaphire sp.1 (CTU-EW.020.h01), A1, A2: Ventral view of male pores region;

B: Lateral view of spermathecal pores region; C1, C2: Right spermathecae; D1, D2: Intestinal caecum; E: Testis sacs and seminal vesicles; F1, F2: Right prostatic gland; G: Copulatory pouch transverse body section; Scale bar $=1 \mathrm{~mm}$ 
Diagnosis. Medium-sized worm, length 157-228 mm, diameter ca. 6.5-8.0 mm, segments 85-145. Prostomium epilobous. Clitellum annular, within xiv-xvi. First dorsal pore in $12 / 13$. Four pairs of spermathecal pores in ventrolateral intersegments 5/6/7/8/9. Male pores on the setal ring in xix; copulatory pouches present. Genital markings absent. Holandric. Testis sacs connected. Intestinal caeca simple. Septa 8/9/10 absent.

Habitat. The species was found in leaflitters or in the top-soil layer, especially in moist places (near streams) or in rocky holes with organic matters. Metaphire sp.1 has a soft body, skin with violet hue when alive, and movement similar to caterpillar locomotion. The species was distributed in mountainous areas, but occasionally found in deltas.

Remarks. The species is very similar to Metaphire anomala (Michaelsen, 1907, but differs in position of male pores, number and position of spermathecal pores, genital markings in male and spermathecal regions and body size.

\section{Metaphire sp.2}

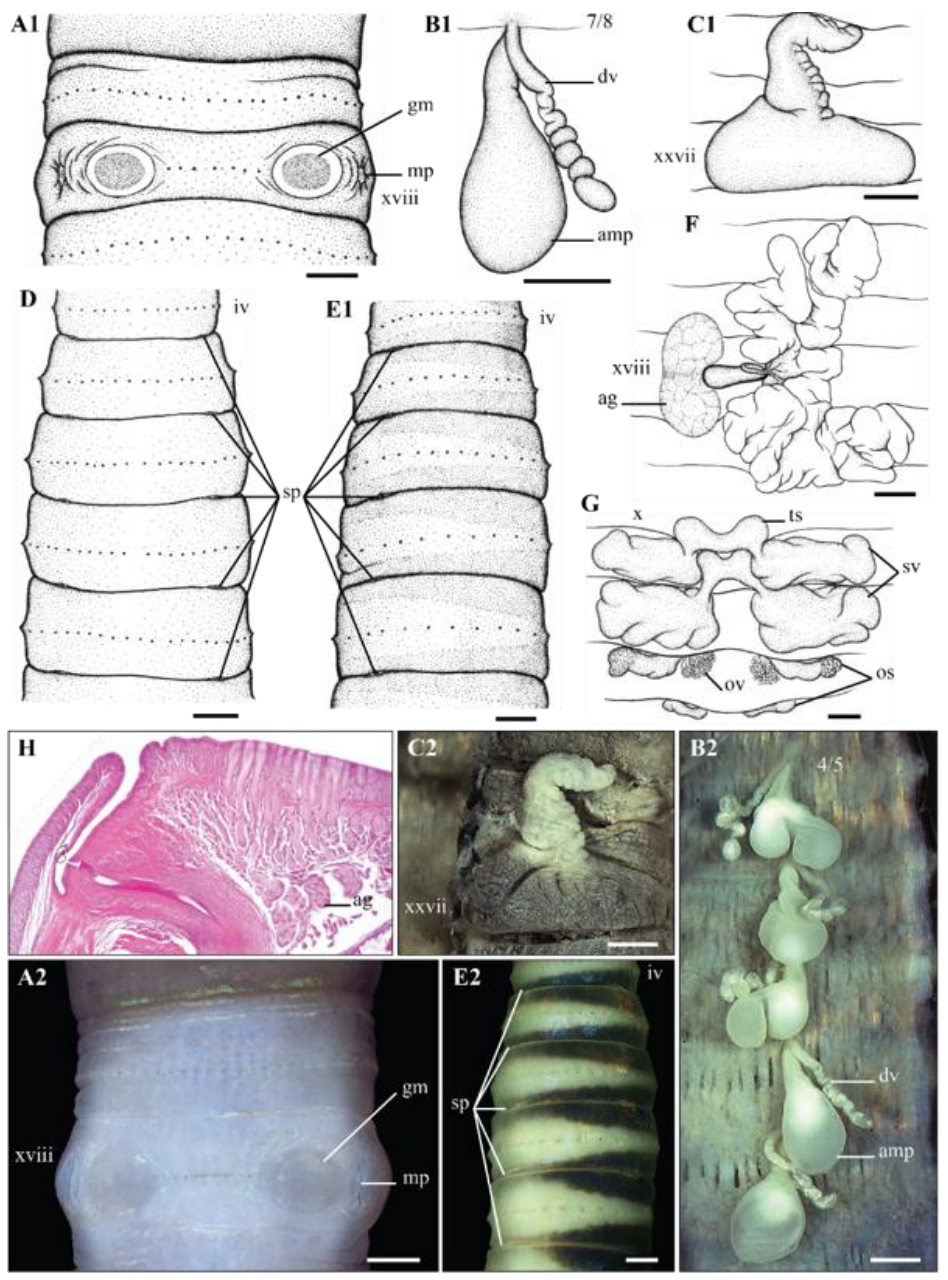

Figure 13. Metaphire sp.2 (CTU-EW.178.h01), A1, A2: Ventral view of male pore region; B1, B2: Right spermathecae; C1, C2: Intestinal caecum; D: Ventral view of spermathecal pore region; E1, E2: Lateral view of spermathecal pores region;

F1, F2: Left prostatic gland; G: Testis sacs and seminal vesicles;

$\mathrm{H}$ : Male pore region transverse body section; Scale bar $=1 \mathrm{~mm}$ 
Materials examined. 1 mature (CTUEW.183.h01), 9 matures (CTU-EW.183.p02), 38 matures (CTU-EW.183.03), natural forest, $8^{\circ} 42^{\prime} 17 \mathrm{~N} 106^{\circ} 35^{\prime} 28 \mathrm{E}, 50 \mathrm{~m}$, Con Son Island, Ba Ria-Vung Tau Province, 19 October 2019; 23 matures (CTU-EW.183.04), natural forest, $8^{\circ} 43^{\prime} 50 \mathrm{~N} 106^{\circ} 37^{\prime} 31 \mathrm{E}, 10 \mathrm{~m}$, Con Son Island, Ba Ria-Vung Tau Province, 18 October 2019; 55 matures (CTU-EW.183.05), residential garden, $8^{\circ} 43^{\prime} 59 \mathrm{~N} 106^{\circ} 37^{\prime} 21 \mathrm{E}, 10 \mathrm{~m}$, Con Son Island, Ba Ria-Vung Tau Province, 18 October 2019, leg. Nguyen Thanh Tung and Nguyen Thi Bao Ngoc.

Diagnosis. Medium-sized worm. Prostomium epilobous. First dorsal pore in 12/13. Clitellum annular, within xiv-xvi. Five pairs of spermathecal pores in ventrolateral intersegments $4 / 5 / 6 / 7 / 8 / 9$. Male pores on the setal ring of xviii; copulatory pouches present. A pair of genital markings in xviii. Holandric. Testis sacs connected. Intestinal caeca simple. Septum 8/9 absent or very thin, 9/10 absent.

Habitats. The species was found in leaf litter of soil layer at the depth of $0-10 \mathrm{~cm}$, near streams, scattered in Con Son Island.

Remarks. The Metaphire sp.2 is very similar to M. megascolidioides (Goto \& Hatai, 1899) with five pairs of spermathecal pores, the first dorsal pore in 12/13 and an absence of genital markings in the spermathecal region. However, Metaphire sp.2 is distinguished by having male pores in xviii, a pair of genital markings in xviii, separate intestinal caeca, and a small size $(\mathrm{l}=64-185 \mathrm{~mm}, \mathrm{~d}=3.0-6.0 \mathrm{~mm})$ whereas $M$. megascolidioides has male pores in xix, three pairs of genital markings in xvii, $\mathrm{x}$ viii and $\mathrm{xx}$, manicate intestinal caeca and a larger size $(\mathrm{l}=240 \mathrm{~mm}, \mathrm{~d}=15 \mathrm{~mm})$.

Genus Polypheretima Michaelsen, 1934

Polypheretima grandisetosa (Thai, 1996)

Materials examined. 6 matures (CTUEW.149.04), natural forest, $8^{\circ} 39^{\prime} 53 \mathrm{~N}$ $106^{\circ} 34^{\prime} \mathrm{OE}, 20 \mathrm{~m}$, Con Son Island, Ba RiaVung Tau Province, 18 October 2019; 2 matures (CTU-EW.149.05), residential garden, $8^{\circ} 43^{\prime} 44 \mathrm{~N} 106^{\circ} 37^{\prime} 39 \mathrm{E}, 10 \mathrm{~m}$, Con Son Island, Ba Ria-Vung Tau Province, 19 October 2019, leg. Nguyen Thanh Tung and Nguyen Thi Bao Ngoc.
Diagnosis. Small to medium-sized worm, length $85-113 \mathrm{~mm}$, diameter $2.6-3.4 \mathrm{~mm}$, segments 204-236. Prostomium undeveloped. Clitellum annular, within xiv-xvi. First dorsal pore in 11/12. Dorsa with 4-6 stout setae in vi or vi-vii; post-clitellar setae $\mathrm{zz}$ more developed than pre-clitellar ones. Two pairs of spermathecal pores in ventral intrasegments $\mathrm{v}$-vi, close to intersegments 5/6/7. Male pores large oval-shaped in xviii; copulatory pouches absent. Genital markings absent. Testis sacs connected. Metandric. Intestinal caeca absent. Septa 7/8/9 and 10/11 absent, 9/10 thin.

\section{Redescription}

Body cylindrical, but the posteriormost part gradually tapering towards telson. Small to medium-size, length $85-113 \mathrm{~mm}$, diameter 2.6-3.4 mm, segments 204-236, weight 0.50.8g. Body uniformly transparent. Prostomium undeveloped. First dorsal pore in 11/12. Pre-clitellar setae stouter and thicker than post-clitellar setae; setal numbers: $43-50$ in viii, 39-47 in $\mathrm{xxx}, 3-4$ between two male pores in xviii, dorsa with 4 to 6 stout setae in vi or vi-vii; post-clitellar setae zz more developed than pre-clitellar ones; setal distance: $a a>a b, \quad z z>z y$. Clitellum annular, within xiv-xvi, light grey, smooth, without setae and dorsal pores. Female pore single, mid-ventral in xiv.

Two pairs of spermathecal pores in ventral intrasegments $\mathrm{v}$-vi, very close to intersegments $5 / 6 / 7$; ventral distance between two pores about 0.25 body circumference. Male pores on very large, highly elevated, oval-shaped porophores in xviii, pushing intersegments 17/18 forward and 18/19 backward; ventral distance between two male pores about 0.27 body circumference. Genital markings absent in both male and spermathecal regions.

Septa 4/5/6/7/8 thick, 7/8/9 and 10/11 absent, $\quad 9 / 10$ and $10 / 11 / 12 / 13$ thin. Oesophageal gizzard between $7 / 8$ and 9/10. Intestinal origin at xv; caeca absent. Last hearts in xiii. Pharyngeal micronephridia developed in 5/6/7. Lymph glands absent. Typhlosole simple, lamelliform. 


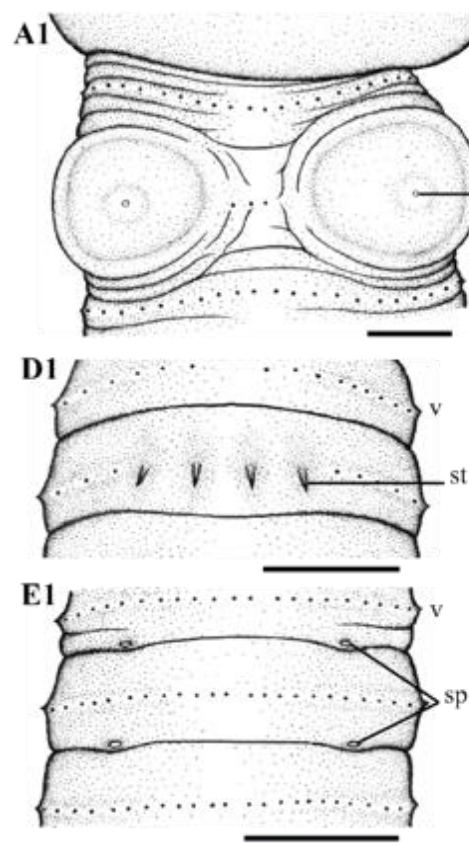

B1
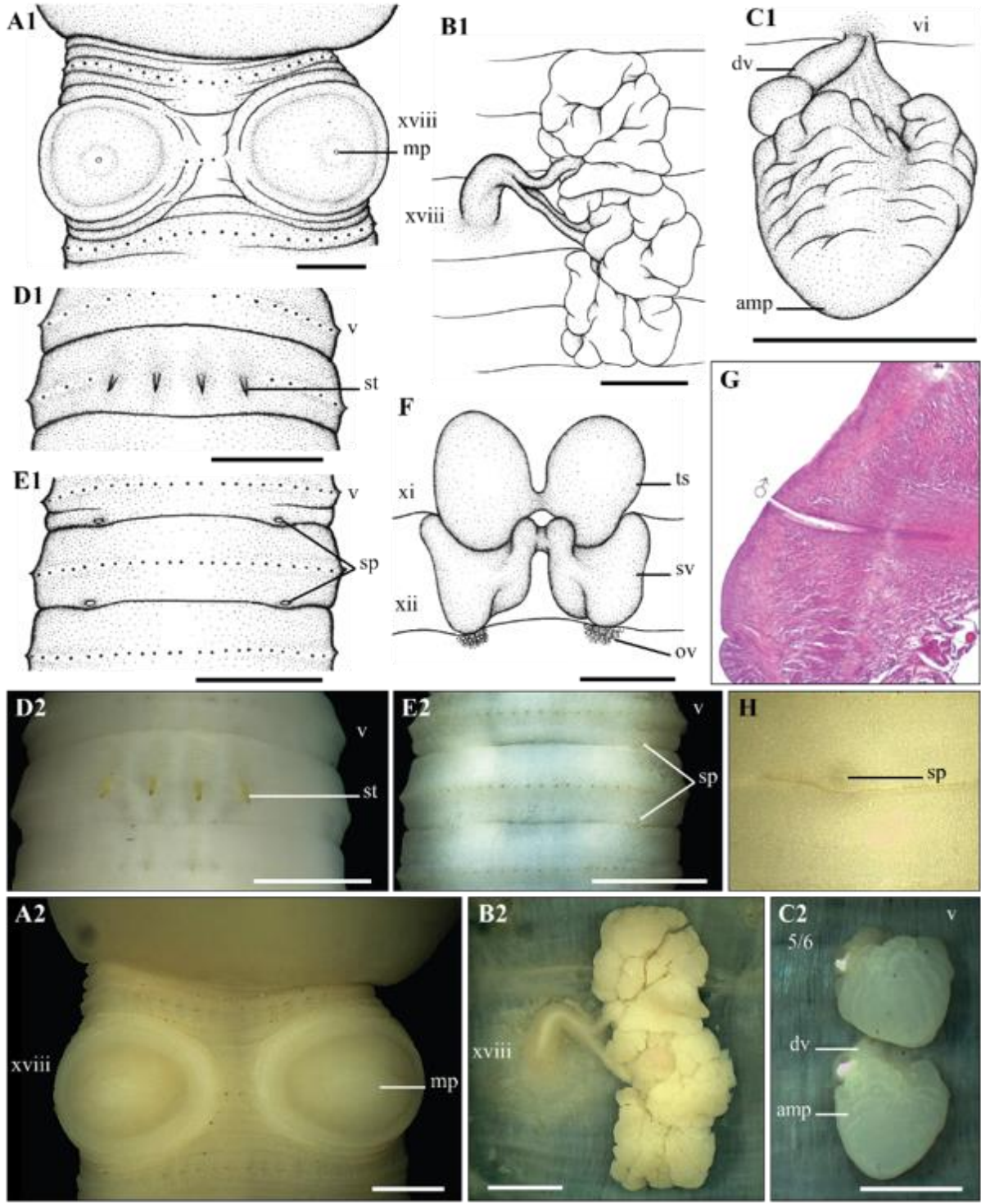

Figure 14. Polypheretima grandisetosa (Thai, 1996), A1, A2: Ventral view of male pores region; B1, B2: Right prostatic gland; C1, C2: Right spermathecae; D1, D2: Dorsal view of spermathecal pores region; E1, E2: Ventral view of spermathecal pores region; F: Testis sacs and seminal vesicles; G: Male pore region transverse body section; Scale bar $=1 \mathrm{~mm}$

Spermathecae paired in $\mathrm{v}$ and vi. Spermathecal ampulla large, mushroomshaped; duct stout, extremely short. Diverticula much shorter than ampulla, attached to the base of ampulla duct; seminal chamber oval-shaped. Accessory glands absent in the spermathecal region.

Metandric. Testis sacs in xi, connected ventrally. Seminal vesicles in xi. Ovaries on septum $12 / 13$, posteriorly. Ovisacs invisible. Prostate glands deeply lobulated, within xvixxi; ducts curved, enlarging basally. Accessory glands absent.

Remarks. Thai (1996) described Pheretima grandisetosa only from juvenile specimens. Our mature specimens slightly differ from the original description in having bigger size (vs. $68 \mathrm{~mm}$ in length, $2 \mathrm{~mm}$ in 
diameter, 184 segments), spermathecal pores located on segment v-vii (vs. located in intersegments 5/6/7), presence of large setae on dorsal vii (vs. absence), presence of septum $9 / 10$ (vs. absence).

Polypheretima colonensis (Thai, 1996)
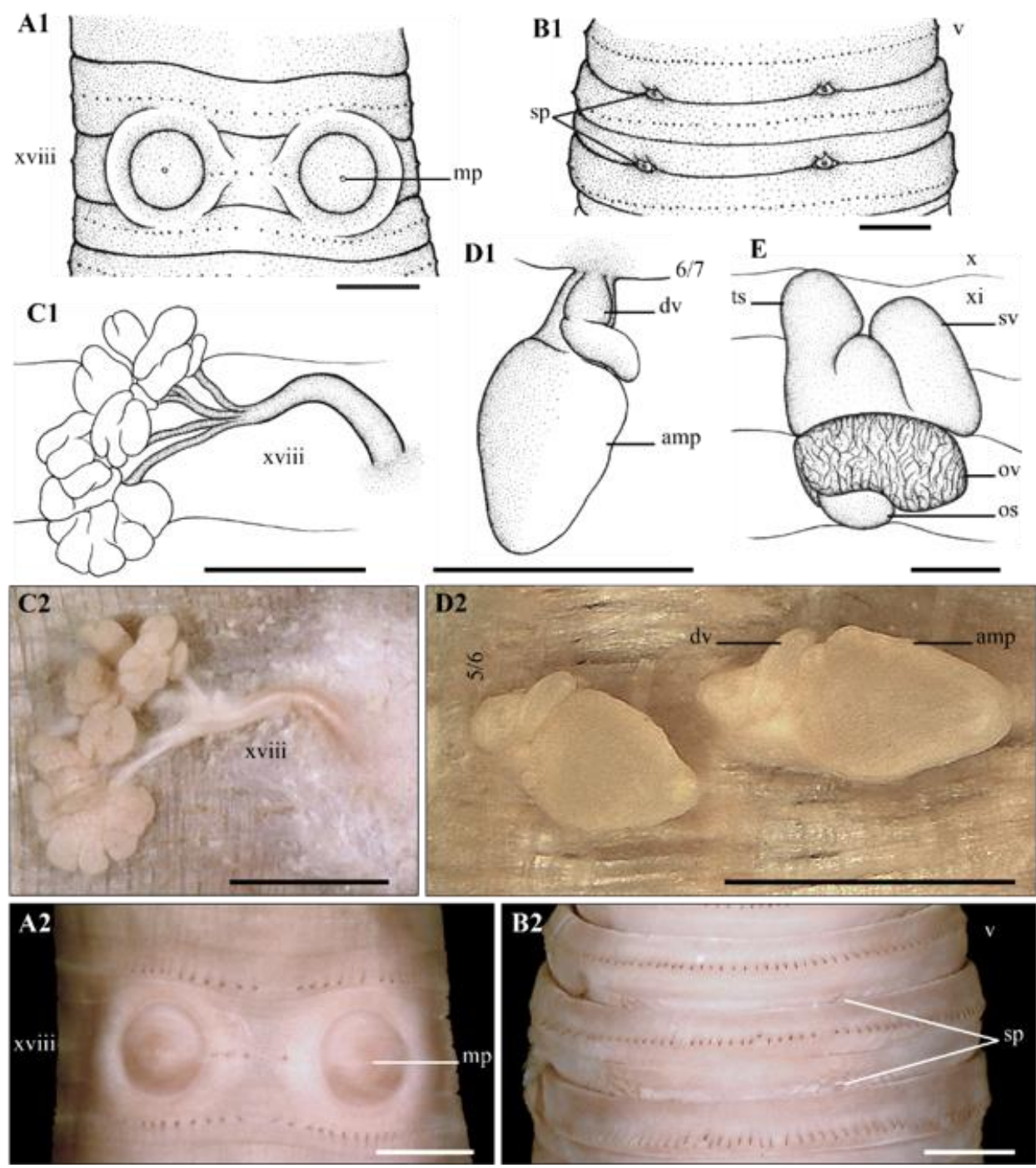

Figure 15. Polypheretima colonensis (Thai, 1996), holotype (CTU-EW.148.h01), A1, A2: Ventral view of male pores region; B1, B2: Ventral view of spermathecal pores region;

C1, C2: Left prostatic gland; D1, D2: Left spermathecae; E: Lateral view of testis sacs and seminal vesicles; D1, D2: Dorsal view of spermathecal pores region;

\section{Scale bar $=1 \mathrm{~mm}$}

Materials examined. 1 juvenile (CTUEW.148.h01), Nha Bang mountain, $100 \mathrm{~m}$, Con Son Island, Ba Ria-Vung Tau Province, 25 June 1989; 1 juvenile (CTU-EW.148.p02), Nha Bang mountain, 6-200 m, Con Son Island, Ba Ria-Vung Tau Province, 26 June 1989, leg. Thai Tran Bai.

Diagnosis. Medium-sized worm. Prostomium undeveloped. Clitellum annular, within xiv-xvi. First dorsal pore in 11/12. Two pairs of spermathecal pores in ventral intersegments 5/6/7. Male pores large roundshaped in xviii; copulatory pouches absent. Genital markings absent. Metandric. Testis 
sacs connected. Intestinal caeca absent. Septa 8/9 and 10/11 absent, 9/10 thick.

Remarks. Thai (1996) described the species Pheretima colonensis only from juvenile specimens. Unfortunately, no fresh specimens were found in our investigation in October 2019.

\section{Genus Pontodrilus Perrier, 1874}

\section{Pontodrilus litoralis (Grube, 1855)}

Diagnosis. Lumbricine. Small-sized worm. Clitellum saddle-shaped, within xiiixvii. Male pores in a concaved area in xviii. Female pores paired, mid-ventral in xiv. Two pairs of spermathecal pores in intersegments $7 / 8 / 9$. Genital markings large, single in ventral intersegment 19/20. Spermathecae one pair per segment. Holandric.

Remarks. Thai et al. (2004) reported that Pontodrilus litoralis was found in saline soils in Con Son Island. Unfortunately, no fresh specimens were found in our investigation in October 2019.

\section{9}

Family OCTOCHAETIDAE Gates,

\section{Genus Dichogaster Beddard, 1888}

Dichogaster bolaui (Michaelsen, 1891)
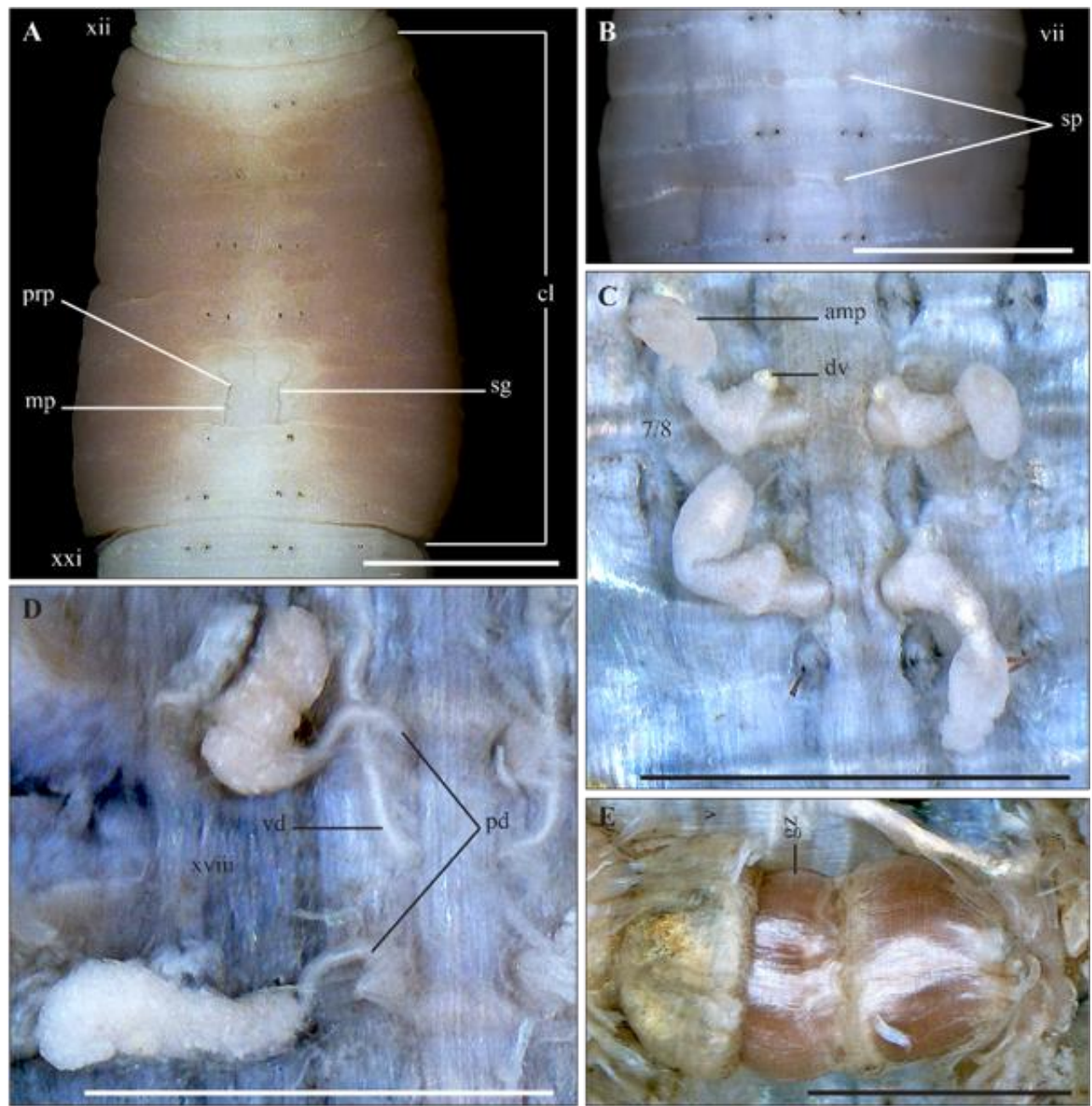

Figure 16. Dichogaster bolaui (Michaelsen, 1891), A: Ventral view of clitellum and male pores region; B: Ventral view of spermathecal pores region; C: Spermathecae;

D: Left prostatic glands; E: Gizzards; Scale bar $=1 \mathrm{~mm}$ 
Materials examined. 1 mature (CTUEW.035.05), natural forest, $8^{\circ} 42^{\prime} 17 \mathrm{~N}$ $106^{\circ} 35^{\prime}$ '28E, $50 \mathrm{~m}$, Con Son Island, Ba RiaVung Tau Province, 19 October 2019, leg. Nguyen Thanh Tung and Nguyen Thi Bao Ngoc.

Diagnosis. Lumbricine. Small-sized worm. Prostomium epilobous. Clitellum saddle-shaped, within xiii-xx. Male pores on seminal grooves in xviii. Prostatic pores in xvii and xix. Female pore mid-ventral in xiv. Two pairs of spermathecal pores in ventral intersegments 7/8/9. Genital markings absent. Spermathecae with small bud-like diverticula attached to the middle of ampulla duct. Nephridia holoic. Gizzards in vi-vii. Intestinal caeca absent.

Remarks. Thai et al. (2004) reported that this species was collected in habitats strongly impacted by human activities. We found only one specimen in natural forests.

Key to earthworm species recorded in Con Dao Island, southern Vietnam

1. - Lumbricine. Clitellum saddle-shaped........................................... 2

- Perichaetine. Clitellum annular................................................. 4

2. - Clitellum in 5 segments xiii-xvii. A pair of genital markings in 19/20

Pontodrilus litoralis

- Clitellum in 8 segments xiii-xx or xv-xxii. Genital markings absent.................... 3

3. - Clitellum xiii-xx. Two pairs of spermathecal pores in ventral 7/8/9. Gizzards paired in vivii......................................................... Dichogaster bolaui

- Clitellum xv-xxii. Three pairs of spermathecal pores in lateral 6/7/8/9. Gizzard in vi... Pontoscolex corethrurus

4. - Clitellum xiv-xvii. Each spermatheca with two diverticula or without diverticula........ .5

- Clitellum xiv-xvii. Each spermatheca with a diverticulum.......................6 6

5. - Three pairs of spermathecal pores in ventrolateral 6/7/8/9. Each spermatheca with two diverticula. Lampito mauritii

- Two pairs of spermathecal pores in ventral 7/8/9. Spermathecae without diverticula. Perionyx excavatus

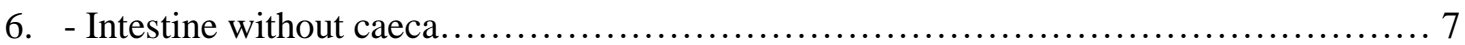

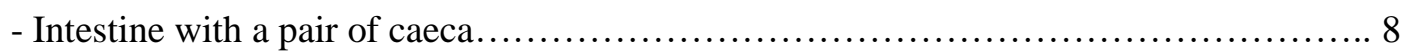

7. - Spermathecal pores in intrasegment. Dorsa with stout setae in vi-vii

Polypheretima grandisetosa

- Spermathecal pores in intersegment. Dorsa without stout setae...Polypheretima conlonensis

8. - Copulatory pouches absent......................................... Amynthas corticis

- Copulatory pouches present........................................................ 9

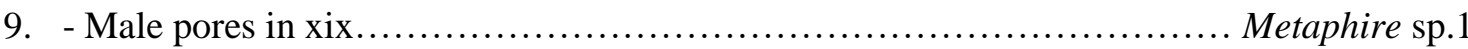

- Male pores in xviii.............................................................. 10

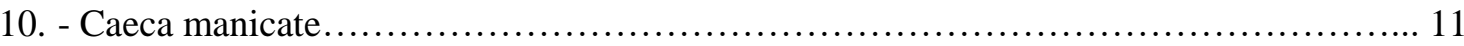

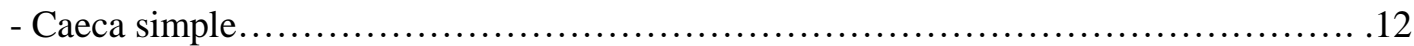

11. - A pair of spermathecal pores in 5/6. Genital markings absent in the male region Metaphire easupana

- Five pairs of spermathecal pores in 4/5/6/7/8/9. Genital markings 1 pair in xviii Metaphire sp. 2 
12. - Genital markings absent in the male region.................................... 13

- Two pairs of genital markings in the male region.................................. 14

13. - Three pairs of spermathecal pores in ventrolateral 6/7/8/9 ............ Metaphire houlleti

- Two pairs of spermathecal pores in lateral 6/7/8...................... Metaphire planata

14. - Four pairs of spermathecal pores in 5/6/7/8/9. Septum 8/9 thickened...Metaphire posthuma

- Three pairs of spermathecal pores in 6/7/8/9. Septum 8/9 absent.................... 15

15. - Genital markings slit-shaped. Male region strongly concave.............. Metaphire bahli

- Genital markings disc-shaped. Male region not concave..... Metaphire peguana peguana

Acknowledgements: This research is funded by Vietnam National Foundation for Science and Technology Development (NAFOSTED) under grant number 106.05-2018.04.

\section{REFERENCES}

Brown G. G., James S. W., Pasini A., Nunes D. H., Benito N. P., Martins P. T., Sautter. K. D., 2006. Exotic, peregrine, and invasive earthworms in Brazil: diversity, distribution, and effects on soils and plants. Caribbean Journal of Science, 42(3): 339.

Feldman A. T., Wolfe D., 2014. Tissue Processing and Hematoxylin and Eosin Staining. In: Day C. (ed.) Histopathology. Methods in Molecular Biology (Methods and Protocols). Humana Press, New York, 1180, pp. 31-43.

Jamieson, 1975. Catalogue of the named Megascolecidae (Oligochaeta: Annelida) in the National Museum of Natural History, Paris. Bulletin du Museum National d'Histoire Naturelle, 286(3e), Zoologie 196: 129-154.

Nguyen T. T, Nguyen A. D, Tran T. T. B., Blakemore R. J., 2016. A comprehensive checklist of earthworm species and subspecies from Vietnam (Annelida: Clitellata: Oligochaeta: Almidae, Eudrilidae, Glossoscolecidae,
Lumbricidae, Megascolecidae, Moniligastridae, Ocnerodrilidae, Octochaetidae). Zootaxa, 4140: 1-92.

Nguyen T. T., 2014. Checklist and some remarks on faunistic characteristics of earthworms in the Mekong Delta, Vietnam. Journal of Science, Cantho University, Section A: Science, Technology and Environment, 32: 106-119.

Sterling E. J., Hurley M. M., Le D. M., 2008. Vietnam: a natural history. Yale University Press.

Thai T. B., 1996. Description of five new species of the acaecate earthworms of the genus Pheretima Kinberg in Vietnam and key to the species of acaecate Pheretima recorded from Indochinese area. Tap chi Sinh hoc, 18(1): 1-6. (in Vietnamese).

Thai T. B., Huynh T. K. H., Nguyen D. A., 2004. Remarks of earthworms on the islands in southern of Vietnam. Proceedings of the national workshop on the basic issues in life science. Hanoi Science and Technics Publishing House: 757-760. (in Vietnamese).

Tran D. T., Le D. A., Nguyen H. C., Tran D. L., Ta H. P., Nguyen V. Q., 2012. Vietnamese sea and islands - position resources, and typical geological and ecological wonders. Natural Sciences and Technology. Ha Noi. Vietnam. (in Vietnamese). 